\title{
Phylogenetic Systematics and Biogeography: Using Cladograms in Historical Biogeography Methods
}

\author{
Raúl Contreras-Medina ${ }^{1}$ and Isolda Luna-Vega ${ }^{2}$ \\ ${ }^{1}$ Escuela de Ciencias, Universidad Autónoma "Benito Juárez" de Oaxaca (UABJO), \\ ${ }^{2}$ Laboratorio de Biogeografía y Sistemática, Departamento de Biología Evolutiva, \\ Facultad de Ciencias, Universidad Nacional Autónoma de México (UNAM),
}

México

\section{Introduction}

Phylogenetic systematics (or cladistics) was proposed by the German entomologist Willi Hennig (1966). Since its formulation it has had a great impact on taxonomy and other biological disciplines such as biogeography, paleontology, and evolutionary biology. In the case of biogeography, phylogenetic systematics has been fundamental and the basis for several historical biogeography approaches, playing a crucial role in the current status of this biological discipline (Crisci, 2001). The term cladistics was first used by authors such as Camin and Sokal or even Ernst Mayr (Schuh, 2000) and was applied to phylogenetic systematic studies that followed Hennig (1966). Notwithstanding that the term cladistics is currently in common use (even a scientific journal has that name), the word cladist was initially used as pejorative, to refer to those authors who used the methods of Willi Hennig (Schuh, 2000).

The methodology of phylogenetic systematics is mainly comparative (Espinosa \& Llorente, 1993) and results in a dendrogram called cladogram (Nelson \& Platnick, 1981), which represents a hypothesis of phylogenetic relationship between the members of the biological group studied. This taxonomic approach proposes sister group relationships among species by common ancestry through the evaluation of character states, avoiding descendantancestry hypothesis, thus eliminating the search of missing links (Espinosa \& Llorente, 1993). Thus cladograms became a powerful way to represent the phylogeny of organisms and communicate these hypotheses to other biologists (Crisci, 2001). From biological and historical perspectives, phylogenetic relationships between taxa and their geographical distribution are considered to be intimately linked to part of the evolutionary process; for this reason it is assumed that a cladogram includes potentially useful information to elucidate the distributional history of organisms and data about the relationships among the areas inhabited by them (Crisci, 2001).

Historical biogeography studies the distribution of organisms, emphasizing processes occurring over millions of years and generally at great spatial resolutions, many times at a worldwide level. In historical biogeography, the proliferation of competing disciplines has 
generated a great number of approaches (Crisci, 2001; Morrone 2009); to this end, several methodologies have been proposed, and the use of taxonomic cladograms is a basic tool in many of them. Among the best-known approaches are: ancestral areas, phylogenetic biogeography, cladistic biogeography, comparative phylogeography, and event-based methods (Crisci et al., 2000).

In this chapter, we briefly discuss the different methods of historical biogeography in which cladograms play an important role, and compare them in the light of the processes that affect the distribution of organisms. For this, we used case studies of animals and plants of Latin America.

\section{Methods of historical biogeography}

\subsection{Phylogenetic biogeography}

This was the first historical biogeographical method that used cladograms as a basic tool to infer biogeographic histories (Crisci, 2001). The approach was proposed by Brundin (1966) and Hennig (1966), and consists of interpreting the biogeographic history of the taxonomic cladogram obtained for a particular taxon, applying two methodological rules: the progression rule and the deviation rule. The first methodological rule assumed that the basal members of a monophyletic group are found closer to/or in the center of origin than those apomorphic members, which are located on the periphery. The deviation rule implies that in any speciation event the apomorphic species accumulate more advanced character states (apomorphies) than the basal species, and are considered more deviated from the ancestor (Morrone et al., 1996).This approach assumes possibilities of dispersal and extinction, and its main concern is to interpret the distributional history of individual taxa. The center of origin could be identified as the area inhabited by the taxon located in the most basal position of the cladogram.

Two studies applying this approach are relevant. The study of Dávila-Aranda (1991) had the main goal of obtaining the phylogeny of a group of species of Sorghastrum (Poaceae) represented in Mexico, and as a secondary objective to propose a biogeographic hypothesis to explain the presence of this genus in Mexico. With this study, Dávila-Aranda separated the most plesiomorphic species of Sorghastrum from the most apomorphic. Reynoso and Montellano-Ballesteros (2004) worked with the desert tortoise genus Gopherus, distributed in northern Mexico and the southern United States. At first, the authors obtained the phylogenetic analysis of tortoises using extant and fossil species; the cladogram obtained was used to reconstruct the biogeographic history of the genus Gopherus. Reynoso and Montellano-Ballesteros (2004) considered that the origin of Gopherus can be traced back to the Oligocene on the Central Plains of North America (where G. laticuneus was found, for them the oldest and most primitive known species of the genus), and later it extended southward from eastern Arizona to Florida (where G. polyphemus inhabits) and from northern Texas to Aguascalientes, Mexico during the Plio-Pleistocene (where G. flavomarginatus occurred); successful expansion of Gopherus during the Pleistocene was followed by a series of extinctions (mainly in Texas and eastern Mexico) and the reduction of the range affecting most of the tortoise species.

This approach is considered to be an eclectic one, because it tries to explain the general patterns of distribution through vicariance and exceptional cases through dispersal. It also 
intended to find the centers of origin of the groups by analyzing the cladograms, and proposed probable routes of long distance dispersal through a dynamic Earth.

\subsection{Ancestral areas}

This approach was developed by Bremer (1992) and it was used for the recognition of an ancestral area of a monophyletic group from the information of its cladogram; this method has been considered the formalization of a cladistic procedure based on a dispersalist approach (Crisci, 2001). It is based on two assumptions: (1) the area located in the basal position of the cladogram (the most plesiomophic) has a high probability of being considered the ancestral area for a particular taxon, in relation to those located in other positions (apomorphics); (2) an area represented in several branches of the same cladogram has a high probability of representing the ancestral area, in relation to those located in few or one branches.

The first step to carry out an analysis of ancestral areas is to construct an area-cladogram, which is obtained from the substitution of terminal taxa by the area or areas where each taxon inhabits; this area-cladogram is analyzed and each area is considered as a binary character with two states (present or absent) and optimized on the cladogram (Crisci et al., 2000). From a comparison of the number of gains and losses, it is possible to estimate which area is considered the ancestral area for the taxon under study, from the highest values observed in gain/loss quotients. This method of historical biogeography is based on dispersal principles and its main concern is the distributional history of individual taxa.

Katinas and Crisci (2000) offered one of the main studies applying this method in South America, based on the flowering plant sister genera Moscharia and Polyachyrus (Asteraceae). In this study, the areas of endemism analyzed were the Coastal Desert, Cardonal, North Central Chile, and South Central Chile provinces. Applying the ancestral areas method, the analysis showed that the most probable area identified as the ancestral area is North Central Chile, which had the highest gain/loss quotient value. According to their results, Katinas \& Crisci (2000) hypothesized that the ancestor of Moscharia and Polyachyrus may have inhabited a part of the area of North Central Chile, and during humid climate periods, the biota of this region increased its range both to the south (South Central Chile) and to the north (Coastal Desert), with the high Andean slopes (Cardonal) being the last area to be occupied.

\subsection{Cladistic biogeography}

This approach was proposed by Rosen (1978), and Nelson \& Platnick (1981); it combines the method of cladistics with theoretical aspects of panbiogeography (Crisci et al., 2000; Espinosa \& Llorente, 1993). Its basic premise is the search for patterns of relationships among areas of endemism (Humphries \& Parenti, 1999). The central axis of this method supposes a relationship between the history of life and history of Earth (Espinosa \& Llorente, 1993).

The first step in cladistic biogeography is to construct area cladograms from taxonomic cladograms, which are obtained by replacing their terminal taxa by the areas of endemism where they occur (Morrone \& Crisci, 1995); from the information of two or more area cladograms, we can apply one or more of the methods that have been proposed in cladistic 
biogeography (see Luna-Vega \& Contreras-Medina in this book), in order to obtain the general area cladogram (Morrone, 2005). The general area cladogram is the final result of any analysis of cladistic biogeography and represents a hypothesis of relationships among areas of endemism analyzed and also reflects vicariance events that occurred in the biogeographic history of the biota analyzed (Contreras-Medina, 2006; Morrone, 1997). One problem detected is related to the basal position of some areas in the general area cladogram, influenced by low diversity or underrepresentation of the biological group studied (e. g. Contreras-Medina \& Luna-Vega, 2002).

The study of the gymnosperm genera Ceratozamia, Dioon and Pinus by Contreras-Medina et al. (2007) is among the studies applying this method in Mesoamerica. In this study, the areas of endemism analyzed were the 19 Mexican floristic provinces proposed by Rzedowski (1981), and the areas of endemism proposed by Morrone (2001) for Central America and by Takhtajan (1986) for North America (see Luna-Vega \& Contreras-Medina in this book). Two methods of cladistic biogeography were applied: Brooks Parsimony Analysis and Paralogyfree Subtrees; the consensus cladogram was obtained from each method. Only two clades were consistent in both consensus cladograms; one clade formed by the Sierra Madre Occidental plus Sierra Madre Oriental-Altiplano provinces, and another clade formed by the Great Basin and Mojavean provinces. These authors considered that both peninsulas of Mexico have a different history in relation to the continental portion of the country.

\subsection{Event-based methods}

This approach creates explicit models of biogeographic processes that affect the geographical distribution of organisms (Crisci, 2001; Morrone, 2009). This approach includes some proposals, one of them being the dispersal-vicariance analysis (or DIVA) proposed by Ronquist (1997). This last method reconstructs the biogeographic history of individual taxa, and also allows reconstruction of biogeographic scenarios that include the possibility of reticulate relationships that do not necessarily follow a hierarchical pattern, as occurs in other methods of historical biogeography (Crisci et al., 2000; Morrone, 2009).

This biogeographic reconstruction is based on a cost matrix, which is constructed according to certain premises (Crisci et al., 2000; Morrone, 2009): (1) vicariance events have a null cost of 0 , which implies that speciation is due to vicariance; (2) duplication events have a null cost of 0 , which is assumed due to sympatric speciation; (3) dispersal events have a cost of 1 per area unit added to a distribution, and (4) extinction events have a cost of 1 per unit area deleted from a distribution.

Among studies applying the DIVA method in South America, we found the study based on several genera of weevils (Curculionidae) by Posadas \& Morrone (2003). In this study, the areas of endemism analyzed were the Maule, Valdivian Forest, Magellanic Forest, Magellanic Moorland, and Falkland Islands provinces. The dispersal-vicariance analysis showed that the most frequent dispersal event involved the Maule-Valdivian Forest $(21.4 \%)$, whereas the most frequent vicariance event involved the separation of the Falkland Islands from the Magellanic Forest-Magellanic Moorland set.

The DIVA has some advantages over other event-based methods, allowing reconstructing biogeographic scenarios, which can include a reticulate area history; colonizations are treated as integral components of evolution of organisms; and additionally, analysis with 
co-occurring taxa can also be used to explore general biogeographic events (Kodandaramaiah, 2010; Posadas \& Morrone, 2003). Although DIVA is an approach to the event-based methods, this method has a low probability of invoking extinctions, inability to distinguish between contiguous range expansions and dispersal across a barrier, and has problems when events of speciation due to dispersal are being erroneously considered as vicariance (Kodandaramaiah, 2010).

\subsection{Comparative phylogeography}

Phylogeography studies the principles and processes governing the geographical distribution of genealogical lineages at intraspecific level using sequences of mitochondrial DNA in animals and chloroplast in plants (Crisci, 2001); it was originally proposed by Avise et al. (1987). Several individuals of the target species are examined along their distribution range, in order to obtain DNA sequences. The sets of similar sequences are recognized as haplotypes and all the information is represented in a phylogeographic tree; the localities (geography) where each specimen was collected are related with the phylogeographic pattern (tree). Generally, results obtained with this approach are based on dispersal principles and dubious clock calibrations (Heads, 2005); its main concern is the distributional history of one species or related species.

The algorithms used to construct taxonomic cladograms, such as parsimony or maximum likelihood are also used to construct phylogeographic trees; the genealogy of haplotypes presents a branched hierarchical structure as observed in taxonomic cladograms, which can be used for a historical biogeographic analysis applying the same principles of the cladistic biogeography (Contreras-Medina, 2006), but at an intraspecific level when comparing two or more phylograms. In this way, the application of comparative phylogeography approach (Arbogast \& Kenagy, 2001) implies the comparison of phylogeographic studies of two or more species that are co-distributed (sympatric), in order to search for common historical patterns of distribution (Zink, 2002; Morrone, 2005).

Among studies applying comparative phylogeography in Mesoamerica, we found the study of Sullivan et al. (2000) based on highland rodents (Peromyscus aztecus/Peromyscus hylocetes complex and Reithrodontomys sumichrasti). The areas considered in this study included several mountain ranges located in Central and Southern Mexico and northern Central America; these mountain chains are the Sierra Madre Oriental, Trans-Mexican Volcanic Belt, Sierra Madre del Sur, Oaxaca Highlands, and the mountains of Chiapas and northern Central America (see Fig. 2 of Luna-Vega \& Contreras-Medina in this book). The results showed that these rodents presented certain common phylogeographic patterns, as well as areas of incongruence. A vicariant pattern between the Oaxaca Highlands and part of the Sierra Madre del Sur was noted, as well as the separation of all mountain ranges in relation to the Chiapas and Central American Highlands, where the Isthmus of Tehuantepec (a lowland region) acted as a barrier and played a relevant role (located in the basal position) of these southern areas. The Sierra Madre Oriental (SMOR) is an example of incongruence, because in the case of Reithrodontomys sumichrasti the SMOR is the sister area of the clade Oaxaca Highlands-Sierra Madre del Sur, while in the Peromyscus aztecus/Peromyscus hylocetes complex the SMOR is sister to the area of the Trans-Mexican Volcanic Belt. 


\section{Comparison of methods}

A comparison of the approaches mentioned in this chapter includes the following aspects: the process involved, reconstruction of biotas or individual histories, and the taxonomic level used in the analysis (Table 1).

Dispersal, vicariance and extinction are of major or minor importance in some of these approaches; dispersal is used mainly in ancestral areas and phylogenetic biogeography, while in the event-based methods, cladistic biogeography and comparative phylogeography dispersal and vicariance are assumed (Crisci et al., 2000); extinction is implemented in all approaches (Crisci et al., 2000). Some methodologies give more importance to the biogeographic history of a particular taxon (ancestral areas, phylogenetic biogeography and phylogeography), while others emphasize the historical relationships among areas of endemism (cladistic biogeography and comparative phylogeography). In analyses based on only one taxon, the concept of center of origin is maintained, e.g. ancestral areas, phylogenetic biogeography and phylogeography. The taxonomic level used in biogeographic analysis is different among these approaches: phylogeography is applied only at species level, while in phylogenetic biogeography, cladistic biogeography and eventbased methods are applied at species level or supraspecific taxa; the ancestral areas method is applied at any taxonomic level (Crisci et al., 2000). The historical relationship between areas and the search of common patterns of distribution are the main objectives in cladistic biogeography and comparative phylogeography.

\begin{tabular}{|c|c|c|c|c|c|}
\hline & $\begin{array}{l}\text { Minimum } \\
\text { number of taxa } \\
\text { to work with }\end{array}$ & $\begin{array}{l}\text { Main } \\
\text { biogeographic } \\
\text { process used }\end{array}$ & $\begin{array}{l}\text { Use of center } \\
\text { of origin } \\
\text { concept }\end{array}$ & $\begin{array}{l}\text { Taxonomic } \\
\text { level used }\end{array}$ & $\begin{array}{l}\text { Explanation } \\
\text { of individual } \\
\text { histories }\end{array}$ \\
\hline \multirow{5}{*}{$\begin{array}{l}\text { Phylogenetic } \\
\text { biogeography } \\
\text { Ancestral areas } \\
\text { Cladistic } \\
\text { biogeography } \\
\text { Event-based } \\
\text { methods } \\
\text { Comparative } \\
\text { phylogeography }\end{array}$} & 1 & Dispersal & Yes & $\begin{array}{c}\text { Species or } \\
\text { genera }\end{array}$ & Yes \\
\hline & 1 & Dispersal & Yes & $\begin{array}{l}\text { Species or } \\
\text { genera }\end{array}$ & Yes \\
\hline & 2 & Vicariance & No & $\begin{array}{l}\text { Species or } \\
\text { genera }\end{array}$ & No \\
\hline & 1 & $\begin{array}{l}\text { Dispersal and } \\
\text { vicariance }\end{array}$ & No & $\begin{array}{l}\text { Species or } \\
\text { genera }\end{array}$ & Yes \& No \\
\hline & 2 & Vicariance & No & $\begin{array}{l}\text { Infra- } \\
\text { specific }\end{array}$ & No \\
\hline
\end{tabular}

Table 1. Main characteristics of the different historical biogeography approaches commented in this chapter.

The development of historical biogeography has been driven by the confrontation of two main biogeographic processes, dispersal and vicariance. Wegener (1929) drew attention to plant distributions, especially of the Southern Hemisphere, where related genera and even congeneric species were separated by vast oceans, representing the living evidence of continental drift (Contreras-Medina \& Luna-Vega, 2002). This distributional pattern has two different historical explanations, which are dispersal and vicariance. The former process involves a common ancestor that originally occurred in one area and later dispersed into another, where its descendants survived until the present day; vicariance implies an 
ancestor that was originally widespread in a larger area that became fragmented, leaving descendants that have survived in the fragments until now (Morrone \& Crisci, 1995) (Fig. 1).

The dispersalist program began with Darwin (1859), especially with his two chapters on geographic distribution, in which the main axis of the Darwinian conception was noted: a random dispersal on a stable geography (Bueno \& Llorente, 1991). This point of view was maintained for more than a century and influenced biogeographical thinking for many decades. This influence is reflected in several methods of biogeography, v. gr. ancestral areas method and phylogenetic biogeography (Morrone, 2005); notwithstanding that these methods used cladograms, the center of origin concept is implemented in both approaches.

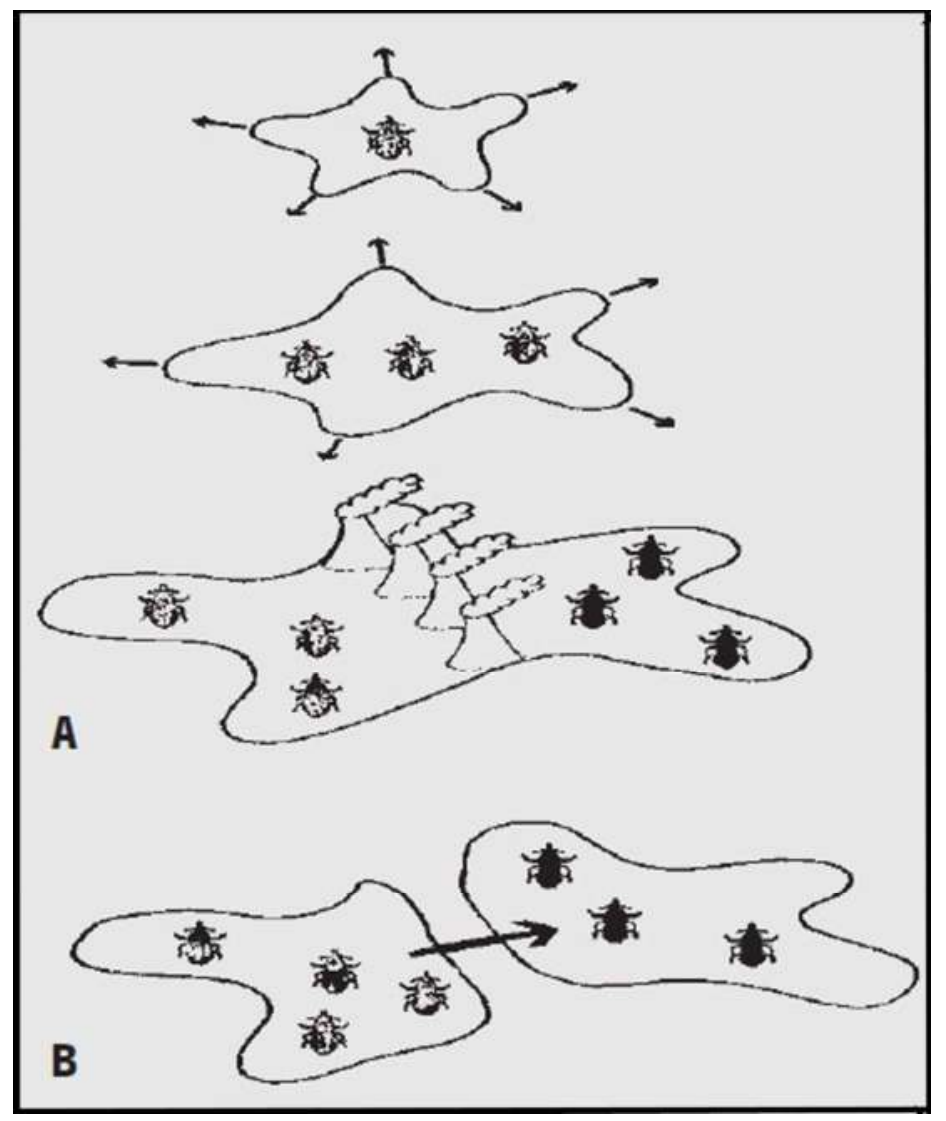

Fig. 1. Historical explanations of disjunct distributions: (A) vicariance, and (B) dispersal. Redrawn from Contreras-Medina et al. (2001).

Vicariance was first considered to be an important component of biogeography after the studies of Croizat $(1958,1964)$; his conception of space as part of the evolutionary process was later included in the cladistic biogeographic approach, which is also known as vicariant biogeography (Espinosa \& Llorente, 1993). This point of view began at the middle of the XX 
century and has influenced biogeographical thinking in recent decades. This influence is reflected mainly in several methods of biogeography, e.g. cladistic biogeography and comparative phylogeography. The use of phylogenies in cladistic biogeography led this approach being considered the most robust method in historical biogeography (ContrerasMedina, 2006; Humphries, 2000).

\section{Conclusions}

The use of cladograms in all the approaches mentioned above is essential and emphasizes the relevance of phylogenetic evidence in historical biogeographic studies. These approaches differ in the number of taxa used for analysis, the interpretation of area cladograms, and in that they give different importance and weight to events that modify the geographic distribution of organisms. In this sense, the effects of extinction can be profound, but they are not commonly considered, many times ignored, in biogeographic studies (Lieberman, 2002). Local extinctions are probably as important as dispersal and vicariance, but unfortunately they are never inferred in biogeographic analyses (Kodandaramaiah, 2010).

It is important to consider that a cladogram represents only a hypothesis of the phylogeny of certain biological group and not necessarily the truth of how the evolutionary history of organisms occurred. If this first hypothesis is contrasted with new evidence, it is possible that the previous topology of the cladogram may change and, in consequence these changes might affect our biogeographic analysis results. Notwithstanding, cladograms are the main source of evidence on phylogeny for all the methods mentioned above and represent the basis for their implementation.

Crisci (2001) considered that the history of life on Earth is complex and we will probably never see it totally revealed. Notwithstanding, historical biogeography is part of the scientific challenge that attempts to resolve the relationship between the history of Earth and the evolution of life; cladograms represent an essential tool for addressing this difficult task.

\section{Acknowledgments}

The first author gives thanks for the honor that the Symposium Committee on Applications of Phylogenies in Botany of the XVIII Mexican Botanical Congress (Guadalajara, Mexico, November 2010) did him by inviting him to present the conference that originated part of this contribution. David Espinosa and Othón Alcántara made constructive comments to the manuscript. RCM dedicates this chapter to his son José Arturo Contreras Córdoba on occasion of his first year of life. Funds for the publication of this contribution were provided by the Secretaría de Planes y Programas Estratégicos directed by Josefina Aranda Bezaury of the Universidad Autónoma "Benito Juárez" de Oaxaca (UABJO). Financial support was given by PAPIIT 221711.

\section{References}

Arbogast, B. S. \& Kenagy, G. J. (2001). Comparative phylogeography as an integrative approach to historical biogeography. Journal of Biogeography Vol. 28, pp. 819-825, ISSN 0305-0270

Avise, J.C., Arnold, J., Ball, R.M., Bermingham, E., Lamb, T., Neigel, J.E., Reeb, C.A. \& Saunders, N.C. (1987). Intraspecific phylogeography: The mitochondrial DNA 
bridge between population genetics and systematics. Annual Review of Ecology and Systematics Vol. 18, pp. 489-522, ISSN 0066-4162

Bremer, K. (1992). Ancestral areas: a cladistic reinterpretation of the center of origin concept. Systematic Biology Vol. 41, pp. 436 - 445, ISSN 1063-5157

Brundin, L. (1966). Transantarctic relationships and their significance, as evidenced by chironomid midges. Kungliga Svenska vetenskapsakadamiens handlingar Vol. 11, No. 1, pp. $437-472$.

Bueno, A. \& Llorente, J. (1991). El centro de origen en la biogeografía: historia de un concepto. In: Historia de la biogeografía: centros de origen y vicarianza. Llorente, J. (ed.), México, D. F., Ciencias Servicios Editoriales UNAM, pp. 1-33. ISBN 968-36-2156-2

Contreras-Medina, R. (2006). Los métodos de análisis biogeográfico y su aplicación a la distribución de las gimnospermas mexicanas. Interciencia, Vol. 31, No. 3, pp. 176182, ISSN 0378-1844

Contreras-Medina, R. \& Luna-Vega, I. (2002). On the distribution of gymnosperm genera, their areas of endemism and cladistic biogeography. Australian Systematic Botany Vol. 15, No. 2, pp. 193-203, ISSN 1030-1887

Contreras-Medina, R., Luna-Vega, I. \& Morrone, J.J. (2001). Conceptos biogeográficos. Elementos Vol. 8, No. 41, pp. 33-37, ISSN 0187-9073

Contreras-Medina, R.; Luna-Vega, I. \& Morrone, J.J. (2007). Gymnosperms and cladistic biogeography of the Mexican Transition Zone. Taxon Vol. 56, No. 3, pp. 905-915, ISSN 0040-0262

Crisci, J.V. (2001). The voice of historical biogeography. Journal of Biogeography Vol. 28, No. 2, pp. 157-168, ISSN 0305-0270

Crisci, J. V., Katinas, L. \& Posadas, P. (2000). Introducción a la teoría y práctica de la biogeografía histórica. Buenos Aires, Sociedad Argentina de Botánica (ISBN 987-97012-4-0) (English translation: 2003, Historical biogeography: An introduction. Cambridge, Mass. Harvard University Press).

Croizat, L. (1958). Panbiogeography. Published by the author. Caracas. 1731 p. ISBN 9780854860340

Croizat, L. (1964). Space, time, and form: The biological synthesis. Published by the author. Caracas. ISBN 978-0854860364

Darwin, C. (1859). El origen de las especies. Planeta-Agostini, Barcelona, Spain. (Spanish version 1992). ISBN 84-395-2172-3

Dávila-Aranda, P. (1991). Consideraciones filogenéticas y biogeográficas preliminares del género Sorghastrum (Poaceae). Acta Botanica Mexicana Vol. 14, 59-73, ISSN-0187-715

Espinosa, D. \& Llorente, J. (1993). Fundamentos de biogeografías filogenéticas. Universidad Nacional Autónoma de México-CONABIO. México, D. F. ISBN 968-36-2984-9

Heads, M.J. (2005). Toward a panbiogeography of the seas. Biological Journal of the Linnean Society Vol. 84, No. 4, pp. 675-723, ISSN 10958312

Hennig, W. (1966). Phylogenetic systematics. University of Illinois Press, Urbana IL, 280 p. ISBN 978-025-2068-140

Humphries, C. J. (2000). Form, space and time: which comes first? Journal of Biogeography Vol. 27, No. 1, pp. 11-15, ISSN 0305-0270

Humphries, C. J. \& Parenti, L. R. (1999). Cladistic biogeography. Oxford University Press, New York. ISBN 019-854818-4

Katinas, L. \& Crisci, J.V. (2000). Cladistic and biogeographic analyses of the genera Moscharia and Polyachyrus (Asteraceae, Mutisieae). Systematic Botany Vol. 25, No. 1, pp. $33-$ 46, ISSN 0363-6445 
Kodandaramaiah, U. (2010). Use of dispersal-vicariance analysis in biogeography - a critique. Journal of Biogeography Vol. 37, No. 1, pp. 3-11, ISSN 0305-0270

Lieberman, B.S. (2002). Phylogenetic biogeography with and without the fossil record: gauging the effects of extinction and paleontological incompleteness. Palaeogeography, Palaeoclimatology, Palaeoecology Vol. 178, No. 1, pp. 39-52, ISSN 0031-0182

Luna-Vega, I. \& Contreras-Medina, R. (2012). Contributions of cladistic biogeography to the Mexican Transition Zone. In: Global advances in Biogeography,L. Stevens (Ed.). InTech, Rijeka, Croatia. ISBN 979-953-307-415-2

Morrone, J.J. (1997). Biogeografía cladística: conceptos básicos. Arbor Vol. 158, pp. 373-388, ISSN 0210-1963

Morrone, J. J. (2001). Biogeografía de América Latina y el Caribe. SEA y M \& T Tesis, Vol. 3, Zaragoza, Spain. ISBN 84-922495-4-4

Morrone, J. J. (2005). Cladistic biogeography: identity and place. Journal of Biogeography Vol. 32, pp. 1281-1286, ISSN 0305-0270

Morrone, J. J. (2009). Evolutionary biogeography: An integrative approach with case studies. Columbia University Press, New York. ISBN 978-0-231-14378-3

Morrone, J. J. \& Crisci, J. V. (1995). Historical biogeography: Introduction to methods. Annual Review of Ecology and Systematics Vol. 26, pp. 373-401, ISSN 0066-4162

Morrone, J.J., Espinosa, D. \& Llorente, J. (1996). Manual de biogeografía histórica. Ciencias Servicios Editoriales, Universidad Nacional Autónoma de México, México, D. F. ISBN 968-36-4842-8

Nelson, G. \& Platnick, N.I. (1981). Systematics and biogeography: Cladistics and vicariance. Columbia University Press, New York. ISBN 0-231-04574-3

Posadas, L. \& Morrone, J.J. (2003). Biogeografía histórica de la familia Curculionidae (Coleoptera) en las regiones Subantártica y Chilena Central. Revista de la Sociedad Entomológica Argentina Vol. 62, No. 1-2, pp. 75-84, ISSN 0373-5680

Reynoso, V.H. \& Montellano-Ballesteros, M. (2004). A new giant turtle of the genus Gopherus (Chelonia: Testudinidae) from the Pleistocene of Tamaulipas, Mexico, and a review of the phylogeny and biogeography of gopher tortoises. Journal of Vertebrate Paleontology, Vol. 24, No. 4, pp. 822-837, ISSN 0272-4634

Ronquist, F. (1997). Dispersal-vicariance analysis: a new approach to the quantification of historical biogeography. Systematic Biology Vol. 46, pp. 195-203, ISSN 1063-5157

Rosen, D.E. (1978). Vicariant patterns and historical explanation in biogeography. Systematic Zoology Vol. 27, pp. 159-188, ISSN 0039-7989

Rzedowski, J. (1981). Vegetación de México. Limusa. Mexico, D.F. ISBN 968-18-0002-8

Schuh, R.T. (2000). Biological systematics, principles and applications. Cornell University Press, New York. ISBN 0-8014-3675-3

Sullivan, J., Arellano, E. \& Rogers, D. S. (2000). Comparative phylogeography of Mesoamerican highland rodents: concerted versus independent response to past climatic fluctuations. The American Naturalist Vol. 155, No. 6, pp. 755-768, ISSN 0003-0147

Takhtajan, A. (1986). Floristic regions of the world. University of California Press, Berkeley. ISBN 0520040279

Wegener, A. (1929). El origen de los continentes y océanos. Planeta-Agostini, Barcelona, Spain (Spanish version 1992). ISBN 84-395-2237-1

Zink, R.M. (2002). Methods in comparative phylogeography, and their application to studying evolution in the North American aridlands. Integrative and Comparative Biology, Vol. 42, No. 1, pp. 953-959, ISSN 1540-7063 


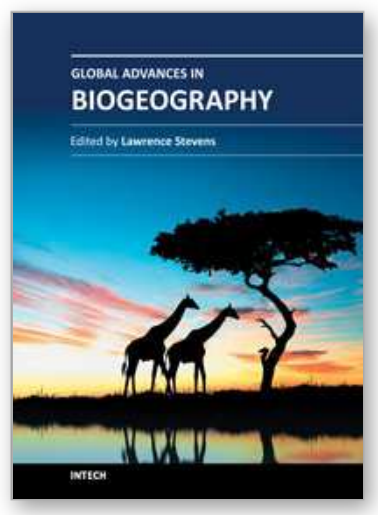

\author{
Global Advances in Biogeography \\ Edited by Dr. Lawrence Stevens
}

ISBN 978-953-51-0454-4

Hard cover, 360 pages

Publisher InTech

Published online 30, March, 2012

Published in print edition March, 2012

Global Advances in Biogeography brings together the work of more than 30 scientific authorities on biogeography from around the world. The book focuses on spatial and temporal variation of biological assemblages in relation to landscape complexity and environmental change. Global Advances embraces four themes: biogeographic theory and tests of concepts, the regional biogeography of individual taxa, the biogeography of complex landscapes, and the deep-time evolutionary biogeography of macrotaxa. In addition, the book provides a trove of new information about unusual landscapes, the natural history of a wide array of poorly known plant and animal species, and global conservation issues. This book is well illustrated with numerous maps, graphics, and photographs, and contains much new basic biogeographical information that is not available elsewhere. It will serve as an invaluable reference for professionals and members of the public interested in global biogeography, evolution, taxonomy, and conservation.

\title{
How to reference
}

In order to correctly reference this scholarly work, feel free to copy and paste the following:

Raúl Contreras-Medina and Isolda Luna-Vega (2012). Phylogenetic Systematics and Biogeography: Using Cladograms in Historical Biogeography Methods, Global Advances in Biogeography, Dr. Lawrence Stevens (Ed.), ISBN: 978-953-51-0454-4, InTech, Available from: http://www.intechopen.com/books/global-advancesin-biogeography/phylogenetic-systematics-and-biogeography-using-cladograms-in-historical-biogeographymethods

\section{INTECH}

open science | open minds

\section{InTech Europe}

University Campus STeP Ri

Slavka Krautzeka 83/A

51000 Rijeka, Croatia

Phone: +385 (51) 770447

Fax: +385 (51) 686166

www.intechopen.com

\section{InTech China}

Unit 405, Office Block, Hotel Equatorial Shanghai

No.65, Yan An Road (West), Shanghai, 200040, China

中国上海市延安西路65号上海国际贵都大饭店办公楼405单元

Phone: +86-21-62489820

Fax: +86-21-62489821 
(C) 2012 The Author(s). Licensee IntechOpen. This is an open access article distributed under the terms of the Creative Commons Attribution 3.0 License, which permits unrestricted use, distribution, and reproduction in any medium, provided the original work is properly cited. 